\title{
Soil microbial biomass under mulch types in an integrated apple orchard from Southern Brazil
}

\author{
Denice de Oliveira Almeida ${ }^{1}$; Osmar Klauberg Filho ${ }^{2 *}$; Henrique Cesar Almeida ${ }^{1}$; Luciano \\ Gebler $^{3}$; Aline Franciane Felipe ${ }^{4}$ \\ ${ }^{1}$ UDESC/CAV - Programa de Pós-Graduação em Manejo do Solo, Av. Luiz de Camões, 2090 - 88520-000 - \\ Lages, $S C$ - Brasil. \\ ${ }^{2}$ UDESC/CAV - Depto. de Solos, Av. Luiz de Camões, 2090 - 88520-000 - Lages, SC - Brasil. \\ ${ }^{3}$ Embrapa/Centro Nacional de Pesquisa de Uva e Vinho, C.P. 1513 - 95200-000 - Vacaria, RS - Brasil. \\ ${ }^{4}$ UDESC/CAV - Programa de Graduação em Agronomia, Av. Luiz de Camões, 2090 - 88520-000 - Lages, SC - \\ Brasil. \\ *Corresponding author < klauberg65@gmail.com>
}

\begin{abstract}
The use of mulching is an alternative to control weeds but there are few studies on its effect on soil quality. In this sense, this study aimed to evaluate the effect of types of mulching on the attributes of microbial carbon, nitrogen and phosphorus in a Typic Hapludox with production of integrated apples in southern Brazil. The experiment was conducted in randomized blocks in the Vacaria, state of Rio Grande do Sul, southern Brazil. The soil mulch types studied were: pine needle, sawdust, black plastic and a control. The soil samples were collected in February (summer) and August (winter) of 2006, and the attributes related to total organic and microbial carbon, nitrogen and phosphorus were determined. Organic mulchings (pine needle and sawdust) promoted lower soil temperature, and greater moisture, microbial carbon (Cmic), microbial nitrogen (Nmic), and the ratios Cmic:Corg, Nmic:Norg and microbial C:N than black plastic. Microbial phosphorus was greater in winter. Sawdust mulching promoted the best conditions to microbial biomass in winter. The mulch types increased the microbial compartment in winter as compared to the nonweeded control.
\end{abstract}

Key words: microbial carbon, soil cover, microbial compartments, microorganisms, organic mulch

\section{Biomassa microbiana do solo sob coberturas em pomar integrado de maçãs no Sul do Brasil}

\begin{abstract}
RESUMO: O uso da cobertura do solo é alternativa para o controle de plantas daninhas. Entretanto há poucos estudos sobre seu efeito na qualidade do solo. Avaliou-se, em duas estações do ano, o efeito de tipos de cobertura do solo nos atributos microbianos de um Latossolo com produção integrada de maçãs no sul do Brasil. O experimento foi conduzido em blocos ao acaso em Vacaria, RS. As coberturas estudadas foram: acícula, serragem e plástico preto comparativamente ao tratamento controle (infestado). As amostras de solo foram coletadas em fevereiro e agosto de 2006, sendo avaliados atributos relacionados ao carbono, ao nitrogênio e ao fósforo. As coberturas orgânicas (acícula e pínus) promoveram no solo menor temperatura e maior umidade, além de maiores teores de carbono e nitrogênio microbiano, relação Cmic:Corg, Nmic:Norg e Cmic:Nmic quando comparadas ao solo sob plástico preto; já o fósforo microbiano foi maior no inverno. A cobertura com serragem promoveu as melhores condições para os compartimentos microbianos no inverno, sendo que nessa mesma estação, as coberturas incrementaram o compartimento microbiano comparativamente ao tratamento controle, infestado com plantas daninhas.

Palavras-chave: carbono microbiano, cobertura do solo, compartimentos microbianos, microrganismos, coberturas orgânicas
\end{abstract}

\section{Introduction}

In Brazil, the apple tree (Malus domestica Borkh) is cultivated in the southern region. The subtropical temperate climate, differently from other Brazilian regions, contributed to the establishment of the apple crops in this area. The apple tree began to be cultivated commercially in South Brazil around the 1970s. In the beginning, the cultivation was conducted in a conventional orchard system. However, recent concerns about sustainable soil use in this region led to the develop- ment of alternative systems for apple production (Maluche-Baretta et al., 2007).

One of the major management problems of orchards is weed control. This control is usually carried out through herbicide use, primarily in conventional systems. The constant use of these chemicals can be harmful to the environment and the organisms in it (Schutte, 2002). Furthermore, soil and water pesticide accumulation can also contaminate plants and fruits used directly in food (ANVISA, 2007).

Sci. Agric. (Piracicaba, Braz.), v.68, n.2, p.217-222, March/April 2011 
In order to find solutions to this problem, many orchards are managed using alternative production systems that utilize conservationist methods of soil management. One such alternative is the integrated system, which includes implementing a management system that tries to reduce or exclude pesticides. There are a number of options, such as weeding, either to keep the bare soil clear, or covering it with different types of mulching, such as bark, straw, crop residues or polyethylene plastic. Soil cover techniques are already used in many parts of the world and for a variety of plant cultures (Gao et al., 2009). However, some soil attributes, such as soil moisture and temperature, may change with the use of these covers, and also vary with the type of mulching used (Liu, 2000).

The type of mulching can modify the biological characteristics of the soil and affect its quality by changing temperature and soil moisture. Quantitative and qualitative changes in soil microorganism population reflect soil quality changes, and they are useful indicators of the effects of any management changes ( $\mathrm{Li}$ et al., 2004).

The changes in soil use affect the ecological balance by reducing or increasing the organic matter intake, with implications for the sensitive soil microorganisms. This is because the $\mathrm{C}, \mathrm{N}$ and other soil elements are recycled mainly through microbial activity and their interactions. Thus, the quantity and diversity of $\mathrm{C}$ compounds used by microorganisms as energy sources affect the elements in the soil. This study aims to evaluate the effect of methods of soil mulching, in two seasons, on the $\mathrm{C}, \mathrm{N}$ and $\mathrm{P}$ microbial compartments in a Typic Hapludox with integrated apple production in southern Brazil.

\section{Material and Methods}

The study was conducted in an integrated apple orchard production in Vacaria, state of Rio Grande do Sul, Brazil (28 33' S; 5047' W, average altitude of $954 \mathrm{~m}$ a.s.l). The climate is characterized as temperate subtropical with summer temperature less than $22^{\circ} \mathrm{C}$ and winter higher than $3^{\circ} \mathrm{C}$, the annual rainfall is $1,750 \mathrm{~mm}$. The orchard, Gala apple variety, was established in 1997 under a Typic Hapludox derived from basalt. The orchard fertilization was in accordance with the fertilization and liming recommendation for the Rio Grande do Sul and Santa Catarina states (1995). The main chemical and granulometric soil characteristics are: $\mathrm{pH}$ (water) $=4.5$, total organic carbon $=24 \mathrm{~g} \mathrm{~kg}^{-1}$, total nitrogen $=2.1 \mathrm{~g}$ $\mathrm{kg}^{-1}$, exchangeable aluminum $=20 \mathrm{cmol} \mathrm{kg}^{-1}$, clay $=670$ $\mathrm{g} \mathrm{kg}^{-1}$, silt $=270 \mathrm{~g} \mathrm{~kg}^{-1}$ and sand $=60 \mathrm{~g} \mathrm{~kg}^{-1}$.

In September 2003, an experiment was set up to evaluate the effect of kinds of mulch. The following treatments were tested: soil cover with pine needles, $0.28 \mathrm{~m}^{3}$ in dry weight $(0.1 \mathrm{~m}$ depth); soil cover with sawdust, 0.25 $\mathrm{m}^{3}$ in dry weight $(0.1 \mathrm{~m}$ depth); soil cover with black plastic and one treatment without weed control. Treatments consisted of tracks of $1 \mathrm{~m}$ width, including five plants. Trees were planted in a spacing of $8 \times 5 \mathrm{~m}$, without irrigation. Each treatment had three replicates, which were arranged in randomized blocks. Mulchings were replaced every year, to the same specifications. Concentrations of $\mathrm{C}, \mathrm{N}$ and $\mathrm{P}$ from organic residues (pine needles and sawdust) were, respectively: 390 and $385 \mathrm{~g} \mathrm{~kg}^{-1}, 1.44$ and $0.63 \mathrm{~g} \mathrm{~kg}^{-1}, 2.9$ and $2.8 \mathrm{~g} \mathrm{~kg}^{-1}$.

Two samplings were carried out, one in February (summer) and one in August (winter) of 2006. One composite sample, with eight cores, was taken from a depth of $0-0.1 \mathrm{~m}$ in each plot. The samples was transported to the lab in a thermic box and kept at constant refrigeration of $4^{\circ} \mathrm{C}$. Soil samples were first passed through a 2 $\mathrm{mm}$ aperture sieve.

For microbial C (Cmic), N (Nmic) and P (Pmic) determinations, the methodology described by Vance et al. (1987) was used, which involves fumigation followed by extraction with potassium sulphate for Cmic and Nmic, and with sodium bicarbonate for Pmic. Cmic concentrations were determined using the methodology described by Walkley and Black (1934). The amount of Nmic was estimated by the Kjeldahl method (Brookes et al., 1985). Cmic and Nmic were determined by titration with ammonium ferrous sulfate, and Pmic by molecular absorption at a wavelength of $882 \mathrm{~nm}$ (Brookes et al., 1982). The Cmic, Nmic and Pmic were obtained by taking at the difference between the fumigated and non-fumigated samples.

Microbial respiration in soil samples was adjusted to $60 \%$ moisture, using the methodology described by Jäggi (1976): samples were incubated in a sealed vial containing a bottle trap with $\mathrm{NaOH}$ at $25^{\circ} \mathrm{C}$ for $48 \mathrm{~h}$. The total organic C (Corg) was determined using the methodology described by Walkley and Black (1934). Total organic N (Norg) was determined by the Kjeldahl method with digestion, distillation and sulfuric acid titration. The levels of $\mathrm{NH}_{4}^{+}$(ammonium) and $\mathrm{NO}_{3}^{-}$(nitrate) were determined after extraction with $\mathrm{KCl}$, distillation and sulfuric acid titration. Soil $\mathrm{P}$ were extracted with Mehlich 1 solution and determined by molecular absorption at a wavelength of $660 \mathrm{~nm}$. All these methods are described in Tedesco et al. (1995). Temperature and moisture were measured on the sampling day, using a geothermometer for temperature and a lab gravimetric method for moisture.

Results were also used to calculate the Cmic:Corg, Cmic:Nmic, Nmic:Norg ratios and the metabolic quotient $\left(q \mathrm{CO}_{2}\right)$; that is, the ratio of microbial respiration to microbial biomass. Following a similar approach to García-Ruiz et al. (2008), a microbial biomass geometric mean (Gma) for each soil sample was calculated as: $\mathrm{Gma}=(\mathrm{Cmic} \times \mathrm{Nmic} \times \mathrm{Pmic})^{1 / 3}$. Results were submitted to an analysis of variance according to the generalized linear model (GLM). The averages were compared by Scheffé test $(p<0.05)$. We used also the Pearson correlation test to check possible links between the various attributes evaluated. 


\section{Results and Discussion}

Microbial carbon (Cmic) was affected by the mulching treatments in the two sampling seasons (Table 1). In summer, this attribute was higher for the plots under pine needle mulching (190.8 $\mathrm{g} \mathrm{g} \mathrm{g}^{-1}$ ), saw- dust $\left(198.1 \mu \mathrm{g} \mathrm{g}^{-1}\right)$ and for the control $\left(212.9 \mu \mathrm{g} \mathrm{g}^{-1}\right)$, when compared to black plastic $\left(115.1 \mu \mathrm{g} \mathrm{g}^{-1}\right)$. The latter provided the lowest values of $\mathrm{Cmic}$ in the soil at this time of the year, with an average $43 \%$ lower than the other mulching treatments. In a study with non-flooded plastic mulching cultivation in rice, Zhejiang province of

Table 1 - Microbial biomass, ratios, nitrate $\left(\mathrm{NO}_{3}^{-}\right)$, ammonium $\left(\mathrm{NH}_{4}^{+}\right)$, soil temperature (Ts) and gravimetric moisture $(\mathrm{Ug})$ in winter and summer in integrated apple orchard under mulchings in Vacaria, RS.

\begin{tabular}{|c|c|c|c|c|c|c|}
\hline \multirow{3}{*}{ Mulching } & \multicolumn{3}{|c|}{ Cmic } & \multicolumn{3}{|c|}{ Nmic } \\
\hline & \multicolumn{2}{|c|}{ Season } & \multirow{2}{*}{ Mean } & \multicolumn{2}{|c|}{ Season } & \multirow{2}{*}{ Mean } \\
\hline & Summer & Winter & & Summer & Winter & \\
\hline & \multicolumn{5}{|c|}{$\mu \mathrm{g} \mathrm{g}^{-1}$} & \\
\hline Pine needle & $190.8 \mathrm{aB}$ & $323.8 \mathrm{bA}$ & 255.3 & $68.3 \mathrm{aA}$ & $79.2 \mathrm{aA}$ & 73.8 \\
\hline Sawdust & $198.1 \mathrm{aB}$ & $395.2 \mathrm{aA}$ & 316.3 & $28.9 \mathrm{bB}$ & $93.3 \mathrm{aA}$ & 67.7 \\
\hline Black plastic & $115.1 \mathrm{bB}$ & $273.9 \mathrm{bA}$ & 195.5 & $45.6 \mathrm{bA}$ & $49.8 \mathrm{bA}$ & 47.7 \\
\hline Control & $212.9 \mathrm{aB}$ & $322.2 \mathrm{bA}$ & 232.2 & $27.1 \mathrm{bB}$ & $56.0 \mathrm{bA}$ & 44.8 \\
\hline \multirow[t]{3}{*}{ Mean } & 179.0 & 334.8 & 256.9 & 42.5 & 70.6 & 56.6 \\
\hline & \multicolumn{3}{|c|}{ Pmic } & \multicolumn{3}{|c|}{ C mic:Corg } \\
\hline & \multicolumn{3}{|c|}{$\mu \mathrm{g} \mathrm{g}^{-1}$} & \multicolumn{3}{|c|}{$\%$} \\
\hline Pine needle & 3.6 & 6.4 & 5.0 & 0.7 & 0.9 & $0.9 \mathrm{a}$ \\
\hline Sawdust & 3.4 & 8.3 & 6.8 & 0.7 & 1.0 & $0.9 \mathrm{a}$ \\
\hline Black plastic & 4.1 & 7.0 & 5.6 & 0.5 & 0.7 & $0.6 \mathrm{~b}$ \\
\hline Control & 5.3 & 6.4 & 5.9 & 0.8 & 1.0 & $0.9 \mathrm{a}$ \\
\hline \multirow[t]{3}{*}{ Mean } & $4.3 \mathrm{~B}$ & $7.1 \mathrm{~A}$ & 5.8 & $0.7 \mathrm{~B}$ & $0.95 \mathrm{~A}$ & 0.83 \\
\hline & \multicolumn{3}{|c|}{ Cmic:Nmic } & \multicolumn{3}{|c|}{ Nmic:Norg } \\
\hline & & & & $\ldots$ & $\%$ & ב-ב \\
\hline Pine needle & $2.7 \mathrm{aA}$ & $4.1 \mathrm{bA}$ & 3.4 & $0.7 \mathrm{aB}$ & 0.8 aA & 0.8 \\
\hline Sawdust & $7.8 \mathrm{aA}$ & $4.2 \mathrm{bA}$ & 5.7 & $0.3 \mathrm{bB}$ & $0.7 \mathrm{aA}$ & 0.5 \\
\hline Black plastic & $2.6 \mathrm{aA}$ & $5.5 \mathrm{aA}$ & 4.0 & $0.4 \mathrm{bB}$ & $0.6 \mathrm{aA}$ & 0.5 \\
\hline Control & $8.0 \mathrm{aA}$ & $5.8 \mathrm{aA}$ & 6.7 & $0.2 \mathrm{bB}$ & $0.5 \mathrm{aA}$ & 0.3 \\
\hline \multirow[t]{3}{*}{ Mean } & 5.30 & 4.92 & 5.1 & 0.4 & 0.76 & 0.5 \\
\hline & \multicolumn{3}{|c|}{$q \mathrm{CO}_{2}$} & \multicolumn{2}{|c|}{$\mathrm{NO}_{3}^{-}$} & $\mathrm{NH}_{4}^{+}$ \\
\hline & \multicolumn{3}{|c|}{$----------\mu \mathrm{gC}-\mathrm{CO}_{2} \mu \mathrm{gC} \mathrm{mic} \mathrm{g}^{-1}$ soil h$^{-1}---------$} & \multicolumn{3}{|c|}{$\mathrm{mg} \mathrm{kg}^{-1} \ldots$} \\
\hline Pine needle & $3.0 \mathrm{bA}$ & $1.8 \mathrm{aA}$ & 2.4 & $3.7 \mathrm{aA}$ & $2.0 \mathrm{aB}$ & $2.8 \mathrm{~b}$ \\
\hline Sawdust & $2.6 \mathrm{bA}$ & $1.5 \mathrm{aA}$ & 1.9 & $6.0 \mathrm{aA}$ & $2.7 \mathrm{aB}$ & $3.8 \mathrm{ab}$ \\
\hline Black plastic & $5.6 \mathrm{aA}$ & $2.6 \mathrm{aB}$ & 4.1 & $2.6 \mathrm{aA}$ & $3.8 \mathrm{aA}$ & $3.9 \mathrm{ab}$ \\
\hline Control & $0.8 \mathrm{bA}$ & $2.3 \mathrm{aA}$ & 1.7 & $5.1 \mathrm{aA}$ & $4.6 \mathrm{aB}$ & $4.6 \mathrm{a}$ \\
\hline \multirow[t]{3}{*}{ Mean } & 3.0 & 2.1 & 2.5 & 4.4 & 3.3 & 3.8 \\
\hline & \multicolumn{3}{|c|}{ Ts } & \multicolumn{3}{|c|}{$\mathrm{Ug}$} \\
\hline & \multicolumn{3}{|c|}{$\ldots$} & \multicolumn{3}{|c|}{ 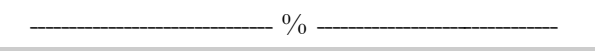 } \\
\hline Pine needle & 21.5 & 10.7 & $15.0 \mathrm{~b}$ & 40.0 & 43.4 & $41.7 \mathrm{a}$ \\
\hline Sawdust & 22.0 & 11.4 & $15.1 \mathrm{~b}$ & 36.3 & 41.0 & $38.5 \mathrm{ab}$ \\
\hline Black plastic & 22.8 & 12.6 & 16.6 a & 35.6 & 40.5 & $38.1 \mathrm{~b}$ \\
\hline Control & 21.1 & 9.9 & $15.5 \mathrm{~b}$ & 38.3 & 40.8 & $39.6 \mathrm{ab}$ \\
\hline Mean & $21.7 \mathrm{~A}$ & $10.9 \mathrm{~B}$ & 16.32 & $37.6 \mathrm{~B}$ & $41.3 \mathrm{~A}$ & 39.5 \\
\hline
\end{tabular}

Upper case $=$ comparison among columns, lower case letters $=$ comparison between lines. Probability associated to the Scheffé test: $p<0.05$. Cmic $=$ Microbial carbon biomass; Nmic $=$ Nitrogen microbial biomass; Pmic $=$ Phosphorus microbial biomass; $q \mathrm{CO}_{2}=$ Metabolic quotient. 
China, Li et al. (2006) also reported a reduction in the soil microbial carbon.

The Cmic was negatively correlated to temperature $(\mathrm{r}=-0.45, p<0.01)$ and positively with soil moisture $(\mathrm{r}$ $=0.68$; Figure 1) under the covers. The effect of black plastic, by providing a higher temperature and lower soil moisture, was crucial to lower soil Cmic content (Table 1). In addition, minor input of fresh organic matter from roots activity and dead plants by weeds control contributed to Cmic reduction.

By forming a protective barrier, the plastic prevented the soil surface receiving rain water directly. As water in the majority of orchards in southern Brazil is supplied through regular rainfall, this type of coverage affects the soil moisture, which is done only through a few infiltration points. These occur mainly around the edges and through any rips or holes that exist in the plastic. The reverse is the case with organic residues, which encourage and retain soil moisture (Costa et al., 2007), and facilitate the infiltration of rainwater through pores while protecting the soil against the wind and the direct sunlight (Tu et al., 2006). In the arid and semi-arid areas, with irrigation taking place below the plastic, the opposite is the case: the plastic mulching serves as a protective barrier against water evaporation from the soil, keeping the moisture in it (Li et al., 2004; 2007).

Because of its lower albedo, the black color of the plastic increased the absorption of solar radiation increasing the soil warming (Li et al., 2007). The opposite occurred with the organic residues, protecting from the sun, because their higher albedo colors, consequently, inducing a lower absorption of the solar radiation. Additionally, the air accumulates around $0.1 \mathrm{~m}$ deep in the mulched layer insulating the soil surface.

In the winter, the greatest concentration of the soil Cmic was provided by sawdust as mulching, with 395.2 $\mathrm{mg} \mathrm{g}^{-1}$ (Table 1). The other kinds of mulch did not differ in the same period. Despite the lower soil tempera-

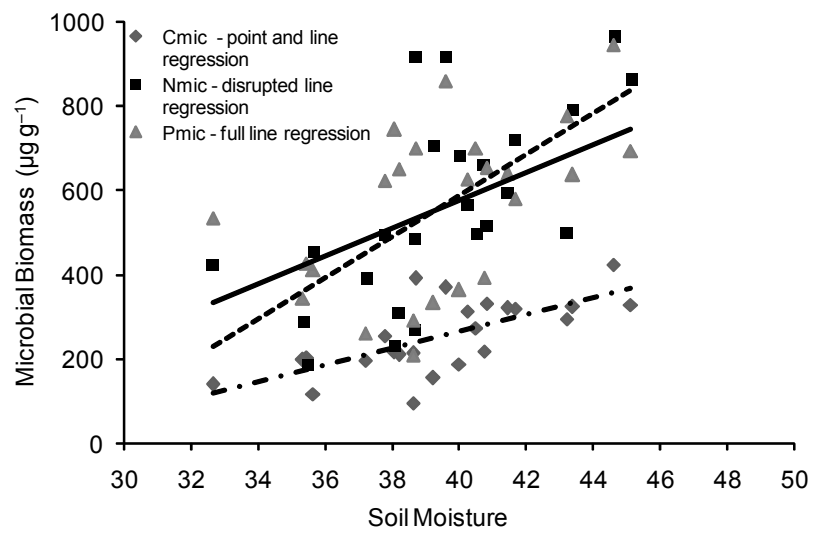

Figure 1 - Microbial carbon (Cmic; $r=0.68$ ), nitrogen (Nmic, values $\mathrm{x} 10 ; \mathrm{r}=0.65$ ) and phosphorus (Pmic, values $\mathrm{x}$ $\left.10^{2} ; \mathrm{r}=0.50\right)$ correlation with gravimetric soil moisture. Probability associated to the Pearson test: $p<0.05$. ture in winter $\left(11^{\circ} \mathrm{C}\right)$, soil moisture and Cmic was greater than in summer for all treatments by $87 \%$ on average. This is also suggested by the existence of a positive correlation between soil moisture and Cmic (Figure 1). In this case, soil moisture was more important to the microbial community than the temperature. A similar fact was noted by Maluche-Baretta et al. (2007) in a Cambisol soil under the same weather conditions, also in an apple orchard, but using a conventional system; however, here the soil Cmic increase was only $22 \%$. In a study involving soil classes in the Rio de Janeiro, Gonçalves et al. (2007) found levels of Cmic 60\% higher in winter. Also corroborating the present work, Piao et al. (2000) found levels of Cmic 58\% higher in winter than in summer in an Ultisol. This author also justifies that Cmic is highly influenced by soil moisture, because many microorganisms are intolerant of low soil moisture and are therefore, controlled by the cycling cycle of wetting and drying soil. However, other factor characteristics of this season that additionally may be influencing high levels of Cmic, and need a more detailed study on this subject.

The Cmic:Corg ratio differed among mulch types and seasons (Table 1). The soil covers with pine needles, sawdust and the weed control provided greater values when compared to plastic. On average these values were between $0.87,0.92$ and $0.94 \%$ for pine needle, sawdust and weeds, respectively, and $0.62 \%$ for the soil under plastic. In winter the Cmic:Corg ratio on average was higher than summer. The soil fresh organic matter accumulation, through the death of weeds as well as the pine needles and sawdust decomposition, provided greater input of carbon to the system, thus stimulating soil microorganism growth. In a study with various organic covers on a sandy soil in the United States, Tu et al. (2006) also showed the effect of such covers on the amount of soil microbial carbon.

There was no difference in soil organic carbon (Corg) between the mulching types, regardless of the season sampled. These values were around $30 \mathrm{~g} \mathrm{~kg}^{-1}$. However, the metabolic quotient $\left(q \mathrm{CO}_{2}\right)$ differed between the kinds of mulch and the seasons (Table 1). In the summer, the plastic-covered soil had a higher $q \mathrm{CO}_{2}$ than the other two kinds of mulch, $5.6 \mu \mathrm{gC}-\mathrm{CO}_{2} \mu \mathrm{gCmic} \mathrm{g}^{-1}$ soil $\mathrm{h}^{-1}$. As $q \mathrm{CO}_{2}$ is a measure of microbial stress, this showed that the higher temperatures and lower moisture generated by the black plastic cover stressed the microorganisms. This is further supported by the correlation between $q \mathrm{CO}_{2}$ and moisture and soil temperature, being negative with moisture $(\mathrm{r}=-0.35, p<0.01)$ and positive with temperature $(r=0.28, p<0.01)$. In the winter, there was no difference between the types of soil mulching, but the plastic decreased soil $q \mathrm{CO}$ from 5.6 in summer to $2.6\left(\mu \mathrm{gC}-\mathrm{CO}_{2} \mu \mathrm{gCmic} \mathrm{g}^{-1}\right.$ soil h$\left.^{-1}\right)$ in winter, a decrease of $46.7 \%$. This again, reflects the microbial instability resulting from seasonality. In a study with organic orchard on same soil and city, Almeida et al. (2009) also showed the same effect of plastic mulch- 
ing on the metabolic quotient in summer; however, in winter the values maintained high in contrast to present study.

The nitrogen in the microbial biomass (Nmic) was higher in the soil covered with pine needles in both seasons (Table 1). With the pine needle mulching, the concentration of this attribute was $68 \mu \mathrm{g} \mathrm{g}^{-1}$ in the summer and $79 \mu \mathrm{g} \mathrm{g}^{-1}$ in winter. This occurred because the pine needles used as mulch had two timed more nitrogen than sawdust ( 1.4 to $0.6 \mathrm{~g} \mathrm{~kg}^{-1}$ ), and hence more of this element is released by decomposition, which favors its detention in microbial tissue. Tu et al. (2006) also found higher microbial organic nitrogen in the mulched soil, detecting differences between levels of Nmic according to the composition of the cover.

The total organic nitrogen (Norg) was not different between covers and times of sampling. These values were around $12 \mathrm{~g} \mathrm{~kg}^{-1}$. However, there was a higher concentration of $\mathrm{NH}_{4}^{+}$in the soil under weeds $\left(4.6 \mathrm{mg} \mathrm{kg}^{-1}\right)$ as compared with the pine needle's coverage $\left(2.8 \mathrm{mg} \mathrm{kg}^{-1}\right.$ ) (Table $1)$. This difference probably occurred because of the differences between the pine needles and the weeds. The roots of weeds continuously cycle nutrients, while there is no such cycling in the soil covered with pine needles, since it provides a total weed control. Mineral $\mathrm{NO}_{3}^{-}$differed between seasons for all treatments except for the plastic cover (Table 1). This can be supported by the physical protection of the plastic against infiltration and consequently, against the percolation of rainwater that causes leaching of $\mathrm{NO}_{3}^{-}$, thus maintaining its levels in the soil, regardless of the time sampled.

There was a greater capacity for the immobilization of nitrogen in the microbial tissue in the organic mulchs in the winter, resulting in the lowest Cmic:Nmic ratio. These figures were 4.1 and $4.2 \%$ for pine needle and sawing, respectively (Table 1 ). The pine needle mulching was the one that immobilized the largest quantity of nitrogen in relation to the total content of this soil element in summer, demonstrated by the ratio Nmic:Norg, with an average of $0.7 \%$. Through immobilization, the microbial community under the mulched soil has a better management of organic nitrogen. As in southern Brazil rains are abundant especially during the winter, this kind of mechanism helps to counter the lack of nitrogen at the same time that it prevents this element contaminating water by the soil holding the nitrogen and preventing leaching therefore reducing the amount of fertilizer required (Erenstein, 2002).

During the winter there was a higher accumulation of nitrogen in the microbial tissue, about $55 \%$ higher than summer, as demonstrated by a greater Nmic:Norg ratio. This is supported by a positive correlation between this ratio and Cmic soil $(\mathrm{r}=0.46, p<0.01)$ and between soil moisture and Nmic ( $r=0.65, p<0.05$; Figure 1). Similarly to Cmic, the soil moisture increased immobilization of nitrogen in the microbial compartment.

There were no differences in the soil microbial phosphorus concentrations from the mulched treatments..
However, averaged for all treatments, the Pmic was higher in the winter than in the summer (Table 1), on average $42 \%$. This suggests that the greater microbial biomass observed at that time had a greater ability to assimilate the $\mathrm{P}$ in microbial biomass. Moreover, the decrease in the metabolism by plant dormancy that promoted the largest $\mathrm{P}$ concentration in soil solution, because roots do not absorb in this stage. This provided more immobilization of inorganic $\mathrm{P}$ by the microorganisms. The $\mathrm{P}$ immobilization is interesting because this labile form is protected of to be bind strongly with iron oxides surfaces, which are present in high concentrations in Brazilian Oxisols. Similar to the microbial carbon observations, there was a positive correlation between the Pmic and soil moisture (Figure 1). There were no differences between treatments and seasonality for extractable phosphorus. These values were around $7 \mathrm{mg} \mathrm{kg}^{-1}$.

The geometric mean ( $\mathrm{Gma}$ ), which is a dimensionless integrator index between soil microbial compartments (Cmic, Nmic and Pmic) demonstrated an interaction between treatment and studied season (Figure 2). In summer, the index did not differ between the mulch types used; however, in winter, the soil sawdust mulched promoted a better index.

Regarding the seasonal effect, the mulchings provided greater Gma in the winter than in summer in contrast to weeds control whose Gma index have not changed. This suggests that the protection promoted in the soil by the mulchings was important in winter, especially in apple cultures that go dormant during this period since they have a reduction on their metabolism. The microbial compartments in this situation are particularly important in protecting against the loss of soil nutrients.

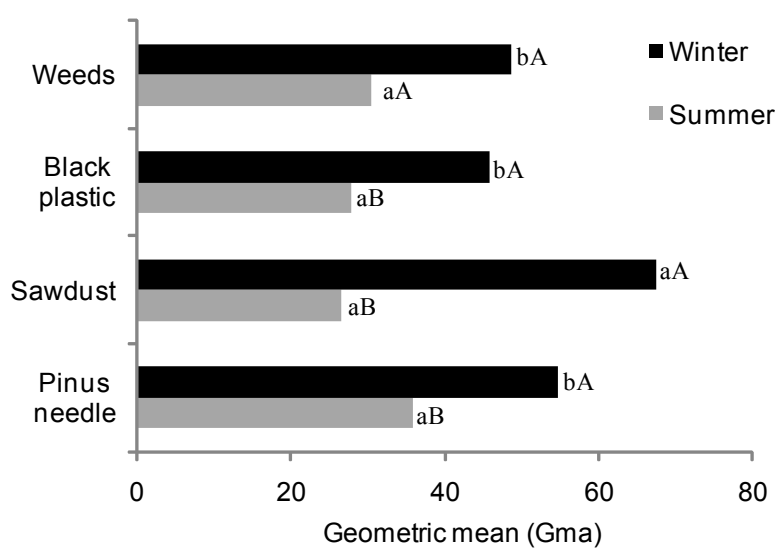

Figure 2 - Geometric mean of microbial compartments in winter (February/2006) and summer (August/2006) in integrated apple orchard under different soil covers in Vacaria, Brazil. Upper case $=$ comparison among seasons, lower case letters = comparison between treatments. Probability associated to the Scheffé test: $p<0.05$. 


\section{Conclusions}

The Cmic, Nmic and $q \mathrm{CO}_{2}$ constituted the main indicators of changes in soil biological quality promoted by covers. These attributes were influenced both by temperature and moisture. Higher soil moisture and lower temperature afforded by the organic mulchings were associated with increases in the concentrations of soil Cmic and Nmic. Contrary results were obtained when black plastic covers were used. All the mulch types provided greater soil microbial compartment in the winter than in the summer. In this same season, the sawdust, provided better conditions for the microbial compartments. Organic mulchings promoted better conditions for microbial quality of the soil.

\section{References}

Agência Nacional de Vigilância Sanitária [ANVISA]. 2007. Program for analysis of pesticide residues in food: analytical results from 2002. Available at: http://www.anvisa.gov.br. [Accessed Dec. 20, 2007].

Almeida, D.; Klauberg Filho, O.; Felipe, A.F.; Almeida, H.C. 2009. Microbial carbon, nitrogen and phosphorus on soil under different mulchings in organic apple orchard in southern of Brazil. Bragantia 68: 1069-1077. (in Portuguese, with abstract in English).

Brookes, D.S., Powlson, D.S.; Jenkinson, D.S. 1982. Measurement of microbial biomass in phosphorus in soil. Soil Biology and Biochemistry 14: 319-329.

Brookes, P.C.; Landman, A.; Pruden, G.; Jenkinson, D.S. 1985. Chloroform fumigation and the release of soil nitrogen: a rapid direct extraction method to measure microbial biomass nitrogen in soil. Soil Biology and Biochemistry 17: 837-842.

Costa, D.M.A.; Melo, H.N.S.; Ferreira, S.R. 2007. Efficiency of the mulch on soil humidity retention. Holos 23: 59-69. (in Portuguese, with abstract in English).

Erenstein, O. 2002. Crop residue mulching in tropical and semitropical countries: an evaluation of residue availability and other technological implications. Soil and Tillage and Research 67: 115-133.

Commission of the Soil Fertility - RS/SC. 1995. Recommendations for Fertilization and Liming for the States of Rio Grande do Sul and Santa Catarina. 3ed. SBCS-RS/SC, Passo Fundo, RS, Brazil. (in Portuguese).

Gao, Y.; Li, Y.; Zhang, J.; Liu, W.; Dang, Z.; Cao, W.; Qiang, Q. 2009. Effects of mulch, $\mathrm{N}$ fertilizer, and plant density on wheat yield, wheat nitrogen uptake, and residual soil nitrate in a dryland area of China. Nutrient Cycling in Agroecosystems 85: 109-121.
García-Ruiz, R.; Ochoa, V.; Hinojosa, M.B.; Carreira, J.A. 2008 Suitability of enzyme activities for the monitoring of soil quality improvement in organic agricultural systems. Soil Biology and Biochemistry 40: 2137-2145.

Gonçalves, A.S.; Monteiro M.T.; Guerra, J.G.M.; Costantini, A.O.; De-Polli, H. 2007. Microbial biomass in air dried and moisturized soil samples from toposequences of pasture. Ciencia del Suelo 25: 81-87.

Jäggi, W. 1976. Determining the measure of $\mathrm{CO}_{2}$ formation as soil biological activity. Schwiez Landwirtschaft Forchung Band 314: 317-380. (in German).

Li, F.M.; Song, Q.H.; Jjemba, P.K.; Shi, Y.C. 2004. Dynamics of soil microbial biomass $C$ and soil fertility in cropland mulched with plastic film in a semiarid agro-ecosystem. Soil Biology and Biochemistry 36: 1893-1902.

Li, S.Y.; Wu, L.H.; Lu, X.H.; Zhao, L.M.; Fan, Q.L.; Zhang, F.S. 2006. Soil microbial biomass as affected by non-flooded plastic mulching cultivation in rice. Biology and Fertility of Soils 43: 107-111.

Li, S.Y.; Wu, L.H.; Zhao, L.M.; Lu, X.H.; Fan, Q.L.; Zhang, F.S. 2007. Influence of continuous plastic film mulching on yield, water use efficiency and soil properties of rice fields under nonflooding condition. Soil and Tillage and Research 93: 370-378.

Liu, X.R. 2000. Research on comprehensive techniques for mulched broad beans in dryland farming areas. Agricultural Research of Arid Areas 18: 40-46.

Maluche-Baretta, C.R.D.; Klauberg-Filho, O.; Amarante, C.V.T.; Ribeiro, G.M.; Almeida, D. 2007. Microbiological and chemical soil attributes in apple orchards under conventional and organic production systems in the state of Santa Catarina, Brazil. Revista Brasileira de Ciência do Solo 31: 655-665. (in Portuguese, with abstract in English).

Piao, H.C.; Hong, Y.T.; Yuan, Z.Y. 2000. Seasonal changes of microbial biomass carbon related to climatic factors in soils from karst areas of southwest China. Biology and Fertility of Soils 30: 294-297.

Schutte, G. 2002. Prospects of biodiversity in herbicide-resistant crops. Outlook Agricultural 31: 193-198.

Tedesco, M.J.; Volkweiss, S.J.; Bohnen, H. 1995. Analysis of soil, plants and other materials. UFRGS, Porto Alegre, RS, Brazil. (in Portuguese).

Tu, C.; Ristaino, J.B.; Hu, S. 2006. Soil microbial biomass and activity in organic tomato farming systems: effects of organic inputs and straw mulching. Soil Biology and Biochemistry 38: 247-255.

Vance, E.D.; Brooks, P.C.; Jenkinson, D.S. 1987. An extraction method for measuring soil microbial biomass C. Soil Biology and Biochemistry 19: 703-707.

Walkley, A.; Black, A. 1934. An examination of Degtjareff method for determining soil organic matter and a proposed modification of the chromic acid Titration method. Soil Science 37: 29-37.

Received January 07,2010

Accepted July 26, 2010 